\title{
Measurement of Dissolved Organic Carbon in Seawater: A Comparison between the High-Temperature Catalytic Oxidation Method and the Persulfate Oxidation Method
}

\author{
JiA-JANG HuNG AND WEI-ANN CHANG
}

\begin{abstract}
A high-temperature catalytic oxidation method (HTCO) has been developed to measure dissolved organic carbon (DOC) in natural seawater. The method employs $\mathrm{Pt} /$ $\mathrm{Al}_{2} \mathrm{O}_{3}$ as a catalyst to oxidize DOC at $680^{\circ} \mathrm{C}$ into $\mathrm{CO}_{2}$ which is detected by a nondispersive $\mathbb{R}$ detector. The detection limit of the method was estimated to be $29.5 \mu M C$ on the basis of a sample volume of $66 \mu \mathrm{l}$. The precision was generally better than $7 \%$ with respect to selected organics added to natural seawater. The detection limit and precision are expected to be lower and greater, respectively, if the injection volume is increased. The HTCO method is faster, more reliable, but higher in analytical cost than the persulfate oxidation method for the analysis of DOC in seawater samples. To obtain reliable values of DOC in a land laboratory, the seawater sample should be filtered, acidified and stored at $4^{\circ} \mathrm{C}$ immediately after sampling. The HTCO method measured the higher values of DOC than did the persulfate method in shelf waters off northeastern and southwestern Taiwan, indicating the incomplete oxidation of the persulfate method. The persulfate method, however, is still recommended for use along with the HTCO method because each method for analyzing DOC provides different geochemical information. The DOC value increases as salinity decreases in surface water off northeastern Taiwan reflecting the influence of terrestrial sources on the distribution of DOC. A vertical decrease of DOC with depth was also found at a station off southwestern Taiwan, indicating that there may be a relationship between DOC distribution and biological turn over of organic carbon. The priorities extended from this study will focus on the spatial and temporal distributions of DOC and their geochemical significance reflected from the use of both methods for marginal seawater under the influence of the Kuroshio.
\end{abstract}

\section{INTRODUCTION}

Measurement of dissolved organic carbon in seawater has been made for over a half century, but no reliable method with direct and/or shipboard performance has been fully recognized yet (Toggweiler, 1990; Sharp, 1991). Previous results obtained from different

Institute of Marine Geology, National Sun Yat-Sen University, Kaohsiung, Taiwan, R.O.C. 
methods revealed that the high-temperature combustion method has higher oxidation efficiency and gives higher DOC values than do the chemical (eg. persulfate) and UV oxidation methods (Menzel and Vaccaro, 1964; Armstrong et al., 1966; Gordon and Sutcliffe, 1973; Sharp, 1973; Gershey et al., 1979; Kumar et al., 1990; Romankevich and Ljutsarev, 1990). However, the high-temperature combustion method has not been widely applied in seawater analysis largely due to problems with contamination and poor reproducibility (MacKinnon, 1978; Sharp, 1991).

Recently, Sugimura and Suzuki (1988) used the high-temperature catalytic oxidation method (HTCO) to measure total concentration of DOC in seawater by means of a Sumigraph N-200 instrument. The method employs $\mathrm{Pt}_{\mathrm{Al}} \mathrm{O}_{3}$ as catalyst to oxidize dissolved organic matter at $680^{\circ} \mathrm{C}$ into $\mathrm{CO}_{2}$ which was subsequently detected by a nondispersive IR. They reported much higher values in both surface and deep water than those previously measured. The results also indicated that the DOC concentration decreases strongly with depth and correlates inversely with apparent oxygen utilization and nitrate concentrations. These striking features suggest that DOC is actively involved in the biogeochemical cycles of carbon (Togweiller, 1989; Bacastow and Maier-Reimer, 1991). The method, however, has not been fully confirmed because no identical results have been reproduced (Toggweiler, 1989; Sharp, 1991). Nevertheless, the HTCO is still the most attractive and potential method to date in measuring DOC in seawater because of its high efficiency in extraction of DOC from seawater.

On the other hand, the persulfate oxidation, which was commonly used to measure DOC previously, has been reported to be far less efficient in recovering DOC from seawater (Sharp, 1973; Sugimura and Suzuki, 1988). Sugimura and Suzuki (1988) also ascribed the persulfate-resistant fraction of DOC to the newly produced, high molecularweight organic compounds in the upper layer of the ocean. The findings may suggest that the simultaneous measurements of DOC with HTCO and persulfate methods are required in order to distinguish the phases of DOC. Nevertheless, the boundary of new and old phases of DOC may not be clear-cut if optimal conditions of persulfate oxidation, which were rarely mentioned before, are not rigorously set for seawater. Therefore, the analytical precision of both methods should be evaluated prior to application on the study of DOC distribution in the oceans.

Although a new set of commercialized HTCO instruments (Sumigraph model TOC90) has been available recently and some DOC results have been revised (Suzuki et al, 1991), we were not inclined to employ this instrument for DOC analysis because of its inacceptably high international price and unknown reliability. Thus we employed the Shimadzu TOC analyzer with a HTCO device for DOC measurements in seawater. The principles of this instrument are basically similar to those of the Sumigraph analyzer, but the price is reasonable enough for us to afford it. The methodology and analytical procedures of the method are addressed as well as the results obtained from the HTCO and persulfate $/ 100^{\circ} \mathrm{C}$ methods are compared and discussed. 


\section{MATERIALS AND METHODS}

\section{a. Instruments}

Analysis of DOC in seawater was established on a commercially available instrument with HTCO oxidation system (Shimadzu TOC 5000), and the results were compared with those from the persulfate $/ 100^{\circ} \mathrm{C}$ oxidation system (O. I. Corporation, model 700). The HTCO system primarily consists of a combustion unit, a gas purification system, a nondispersive IR (NDIR) detector and a recording system. The water sample was injected into an oxidation column of quartz material containing either normal catalyst (Pt-alumina) or high sensitivity catalyst (Pt-quartz wool), depending on the type of measurement. The column is housed in an electric fumace which is continuously heated at $680^{\circ} \mathrm{C}$ under the atmosphere of purified air. The generated $\mathrm{CO}_{2}$ was carried by purified air to the NDIR detector, and the signal was digitally converted into carbon concentration according to the calibration of DOC standards. In case of the model $700 \mathrm{O}$. I. analyzer, the instrument is widely known in the oceanographic community and detailed description is not necessary. Usually the seawater is directly injected into the system, and dissolved $\mathrm{CO}_{2}$ is expelled from the acidified seawater by purging with nitrogen. The remaining DOC is then oxidized by persulfate at $100^{\circ} \mathrm{C}$ and the released $\mathrm{CO}_{2}$ is measured by a NDIR detector. Standard calibration should be made and recorded in the analyzer prior to analysis of seawater samples.

\section{b. Calibration}

A standard stock solution ( $1000 \mathrm{ppm} \mathrm{C}$ ) was prepared for both methods by dissolving analytical-grade potassium hydrogen phthalate (Merck) in $0.4 \% \mathrm{HCl}$ solution $(v \mathrm{HCl}$ : $v Q$ $\mathrm{H}_{2} \mathrm{O}$ ), stored at $4^{\circ} \mathrm{C}$ in the dark. Working standard solutions were prepared by dilution of stock solution in $0.4 \% \mathrm{HCl}$ solution. Standard stock and working standard solutions should be prepared weekly and daily, respectively. The injection volume of each sarnple for the HTCO method can be selected (100 $\mu l$ max. for using normal catalyst) and operated by an automatic injector, thus the standard solution and seawater were injected with $66 \mu l$ throughout this experiment. Peak areas (integrated counts) of standards were leastsquare fitted and the concentration of seawater sample was calculated from this calibration.

The calibration of persulfate method was made from a single standard. The working standard $(10 \mathrm{ppm})$ was nun repeatly by introducing $0.5 \mathrm{ml}$ into the model 700 analyzer to react with $3 \mathrm{ml}$ of persulfate for $13 \mathrm{~min}$. until the detector response was constant; the blank-corrected scaling factor $(\mu \mathrm{gC} / \mathrm{mV})$ was used to calculate the DOC concentration in seawater.

\section{c. Verification}

The recovery of organic compounds spiked in natural seawater was examined to 
realize the precision of the HTCO method. The same experiment was also conducted for the persulfate $/ 100^{\circ} \mathrm{C}$ oxidation method.

\section{d. Analysis of DOC in seawater}

Seawater samples were collected on board the R/V Ocean Researcher 1 with Niskin bottles $(2.5 \mathrm{l})$ mounted on a Rosette sampler from a station (st. A) off southwestern Taiwan and stations (sts. 1-11) of a transect off northeastern Taiwan (Figure 1) during the periods of 20-26 August and 4-7 October, 1991, respectively. One liter of each sample was filtered through the pre-combusted $\left(450^{\circ} \mathrm{C}, 4 h\right.$ ) glass-fiber filter (Whatman GF/F) which was mounted on a Swin-Lock filtration holder (Nucleopore). After discarding the first $800 \mathrm{ml}$ of filtrate, a subsequent $100 \mathrm{ml}$ of filtrate was transferred to the seawater pre-

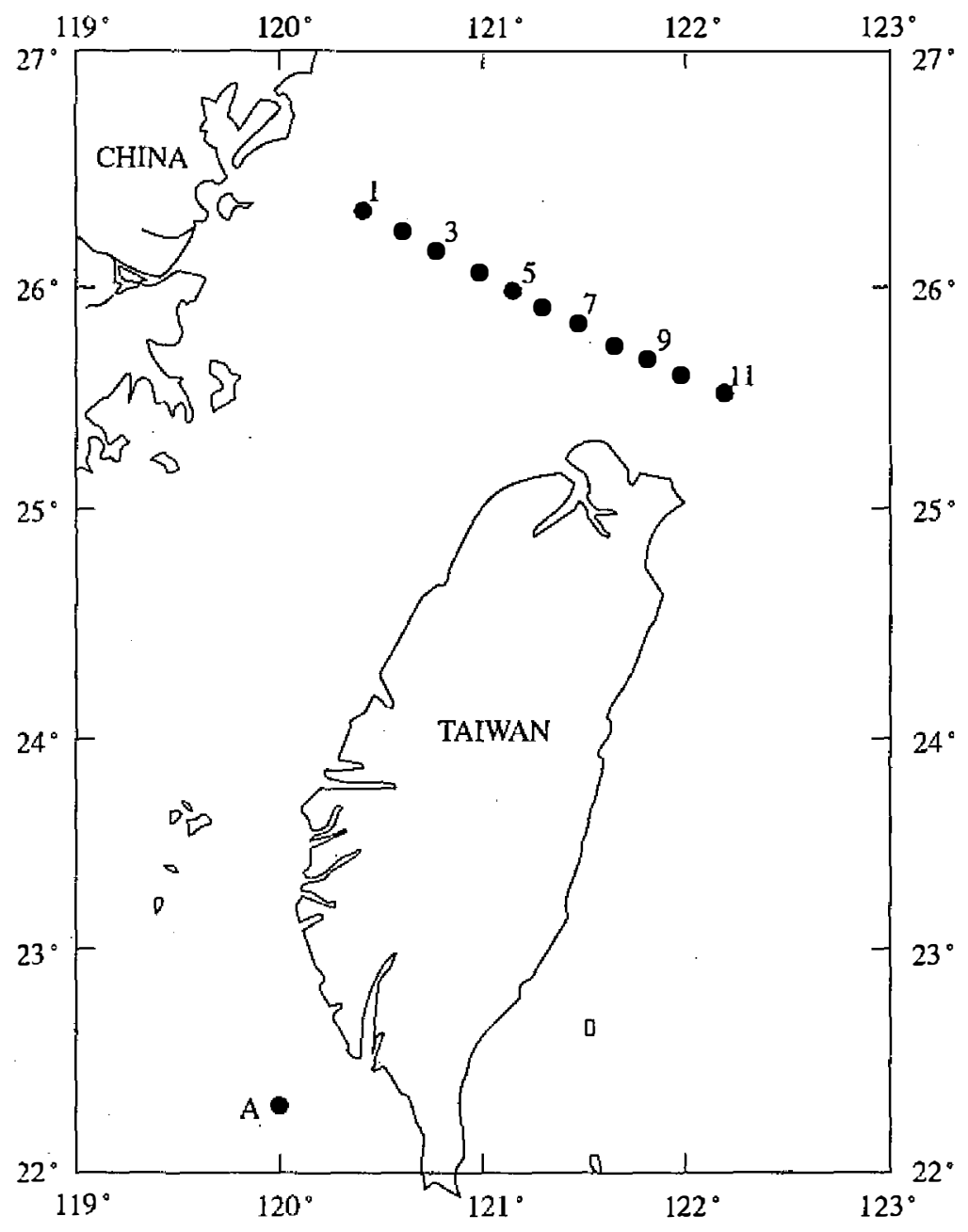

Fig. 1. The map of sampling locations. 
rinsed Pyrex glass bottle. The filtrate was immediately acidified with $0.4 \mathrm{ml}$ of subboiled $\mathrm{HCl}$ and then stored at $4^{\circ} \mathrm{C}$ until analyses at a land-based laboratory. The determination of DOC in seawater by the HTCO method was carried out by purging $20 \mathrm{ml}$ of filtered and acidified seawater in a Pyrex test tube with purified air for $5 \mathrm{~min}$. to remove dissolved $\mathrm{CO}_{2}$. The $66 \mu l$ of decarbonated seawater was injected into the oxidation column by means of an automatic syringe. Each sample was run for at least 5 repeated measurements, and abnormal signals were deleted to ensure that the standard deviation of repeats was less than $2 \%$. The averaged running time for a sample was estimated to be $12 \mathrm{~min}$.

If DOC was determined by the persulfate method, a volume of $0.5 \mathrm{ml}$ acidified and purged seawater was allowed to react with $3 \mathrm{ml}$ of $10 \%(\mathrm{w} / \mathrm{w})$ potassium persulfate for $13 \mathrm{~min}$. At least three repeats, which usually last longer than $45 \mathrm{~min}$., were performed for a sample ensuring that the standard deviation of repeats was less than $5 \%$.

\section{RESULTS AND DISCUSSION}

\section{a. Calibration}

Calibration of the HTCO method was based on four-point (2, 4, 6 and 8 ppm C) standards. Output signals (integrated counts) of the four standards were perfactly linear with respect to carbon concentrations as shown in Figure 2. The intercept of regression line on the $y$-axis indicates the blank signal derived from the instrument (system) itself and the matrix of standard solution (acidified Q- $\mathrm{H}_{2} \mathrm{O}$ ). The matrix blank was not evaluated

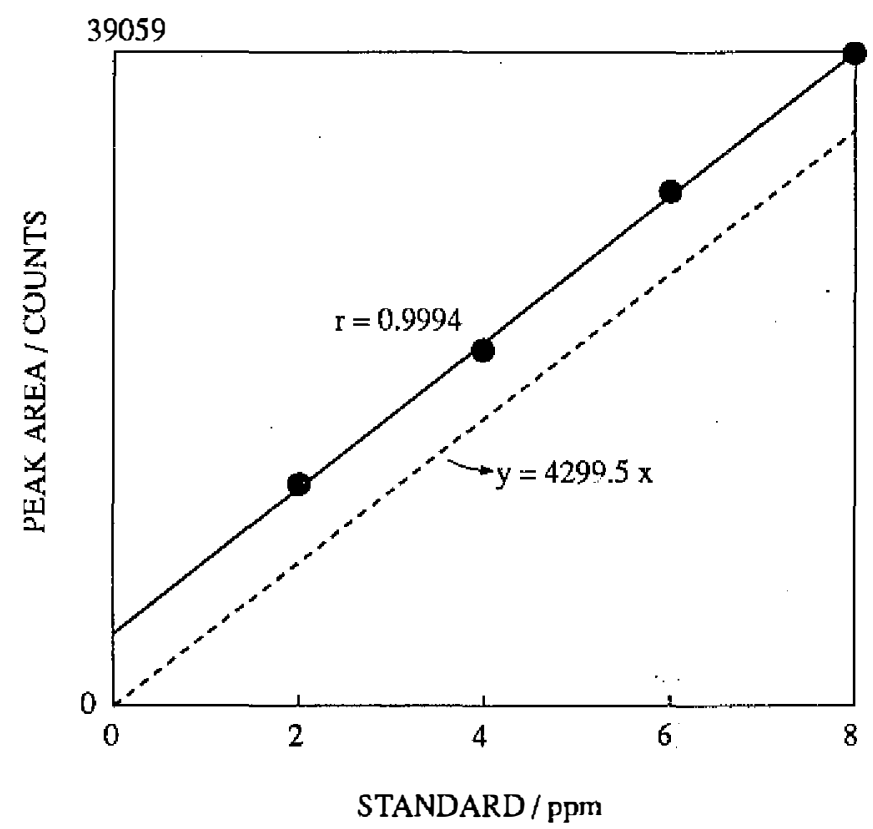

Fig. 2. The calibration curve of DOC standard (-) and shift of the curve to pass the origin (---). 
directly because organic-carbon free Q- $\mathrm{H}_{2} \mathrm{O}$ was not available. The effect of different matrices on the DOC measurement was not thought significant, because a comparable method has been proved to be effective in the oxidation of DOC in natural seawater (Sugimura and Suzuki, 1988). The non-target gases such as $\mathrm{Cl}_{2}$ and $\mathrm{SO}_{2}$ produced from the combustion of seawater, which may affect the DOC detection, have been removed by a halogen scrubber before $\mathrm{CO}_{2}$ entered the NDIR detector. The system blank, which may come from the carrier gas, catalysts (Pt-alumina) and carry-over (memory.) residue during consecutive injections, however, must be known because it is included in the measuring signals of the following natural seawater samples. In practical analysis, the signal of a seawater sample (including system blank) was converted to carbon concentration according to the calibration of net response by shifting the y-intercepted calibration line to pass the origin. The concentration of DOC in seawater sample, therefore, contains a part of carbon derived from the blank. Furthermore, the memory blank, which may be a part of system blank, can stem from the incomplete combustion of organic carbon in the oxidation column and/or adsorption of carbon on the surface of catalyst. This carry-over blank may not be consistently same throughout the measurements and this may result in the variability of the system blank during the experiment. To evaluate this memory blank of HTCO analyzer, samples of seawater and Q- $\mathrm{H}_{2} \mathrm{O}$ were alternatively measured with five injections for each determination. From Table 1 , we found that the signal of the first injection is usually but not always higher than those of the other injections for the Q- $\mathrm{H}_{2} \mathrm{O}$ sample. It should be mentioned that standard deviations of repeated measurements are generally greater than $2 \%$ because the data were presented as original counts, and no abnormal count has been deleted. The results indicate that the memory blank may not be neglected when the measurement is switched from the sample of relatively high carbon to the sample of relatively low carbon. In order to avoid the daily variability of system blank, we thus did not consider the value of first injection between samples to eliminate the possibil-

Table 1. Alternative measurements of DOC between seawater (SW) and Q- $\mathrm{H}_{2} \mathrm{O}$ by the Shimadzu TOC 5000 analyzer

\begin{tabular}{|c|cccccccc|}
\hline inj. & SW & Q- $\mathrm{H}_{2} \mathrm{O}$ & $\mathrm{SW}$ & $\mathrm{Q}-\mathrm{H}_{2} \mathrm{O}$ & $\mathrm{SW}$ & $\mathrm{Q}-\mathrm{H}_{2} \mathrm{O}$ & $\mathrm{SW}$ & $\mathrm{Q}-\mathrm{H}_{2} \mathrm{O}$ \\
\hline 1 & 7704 & 3191 & 8189 & 2717 & 8313 & 2923 & 8437 & 3805 \\
2 & 7938 & 2629 & 7897 & 2802 & 8473 & 2727 & 8322 & 2799 \\
3 & 8064 & 2712 & 8021 & 2706 & 8081 & 2888 & 8283 & 2916 \\
4 & 8080 & 2596 & 8084 & 2562 & 8084 & 3117 & 8212 & 2876 \\
5 & 8380 & 2621 & 7990 & 2606 & 8533 & 2764 & 7964 & 2960 \\
mean & 8033 & 2749 & 8036 & 2678 & 8296 & 2883 & 8240 & 2927 \\
(sd.) & $(245)$ & $(250)$ & $(108)$ & $(95)$ & $(211)$ & $(154)$ & $(183)$ & $(106)$ \\
\hline
\end{tabular}

inj.: injection number 
ity of memory effect for samples of natural seawater. Under these conditions, the system blank is estimated from the $y$-intercepts of zero volume extrapolated from regression lines between integrated counts and different volumes of injections for various solutions (Figure 3). The greater signals of solution $\mathrm{C}$ ( 2 ppmC in $3 \% \mathrm{NaCl}$ ) over solution $\mathrm{B}(2 \mathrm{ppmC}$ in Q$\mathrm{H}_{2} \mathrm{O}$ ) are ascribed to be largely derived from the organic carbon contamination of $\mathrm{NaCl}$ solution rather than from the matrix effect, because the solution of $\mathrm{KHP}(2 \mathrm{ppm})$ prepared from pre-combusted $\mathrm{NaCl}\left(450^{\circ} \mathrm{C}, 6 \mathrm{hr}\right)$ gave the less carbon signal than did the same concentration of KHP solution prepared from non-combusted $\mathrm{NaCl}$. The averaged integrated counts of the system blank were estimated at 762 , which is equivalent to $11.69 \mathrm{ngC}$. This value is equal to be $14.75 \mu M C$ in the seawater volume of $66 \mu l$, which was considered as the minimum running system blank. It was always subtracted from DOC concentration of seawater samples converted from the origin-passing calibration.

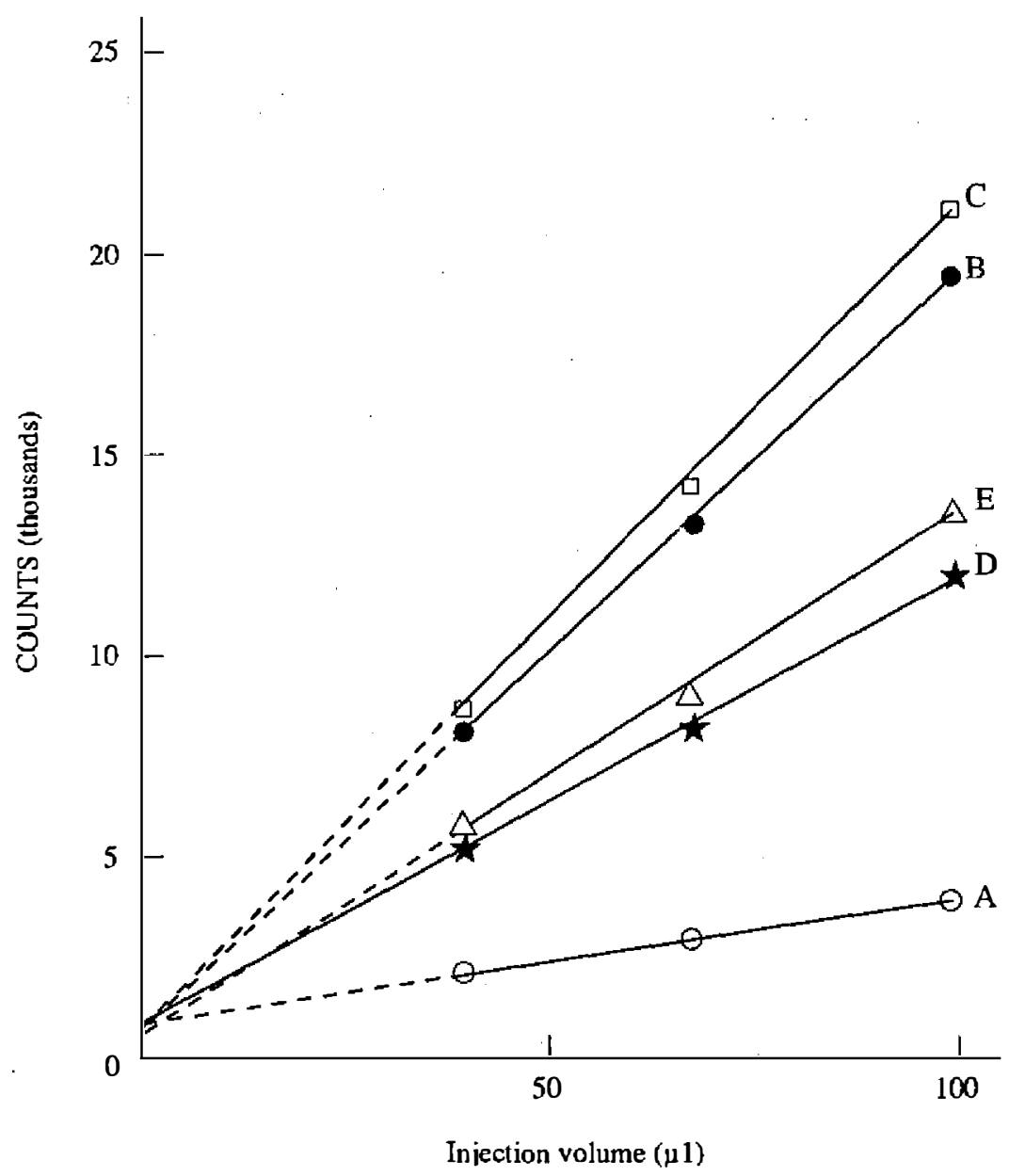

Fig. 3. Relationship between the measuring signals (counts) and injection volumes of various solutions: Q- $\mathrm{H}_{2} \mathrm{O}(\mathrm{A}), \mathrm{KHP}(2 \mathrm{ppm})$ in Q $\mathrm{H}_{2} \mathrm{O}(\mathrm{B}), \mathrm{KHP}(2 \mathrm{ppm})$ in $3 \% \mathrm{NaCl}(\mathrm{C})$, and samples of different seawaters (D and $E)$. 
The blank of the persulfate method, which comes mainly from reagents, gas, tubing and digestion chamber, is dependent upon the introduced reagent volume. It was generally found to be around $10 \mathrm{mV}$ on the basis of $3 \mathrm{ml}$ of oxidant, which should be subtracted from the signals of standards and samples. The blank was roughly equivalent to $0.45 \mu g C$. This blank is subject to variability and should be checked prior to running standards and samples. The instrument uses $\mu \mathrm{gC} / \mathrm{mV}$ as scaling factor to convert the measured voltages from samples to DOC concentrations. The linear range of the NDIR detector was reported up to $50 \mu g C$ (Operating Manual of O. I. Instrument), which far exceeds the $5 \mu g C$ in the standard solution.

\section{b. Verification of DOC measurements in seawater}

The reliability of DOC measurements in seawater by means of HTCO and persulfate/ $100^{\circ} \mathrm{C}$ methods was examined from the recovery of various amounts of organic compounds (KHP, EDTA, oxalic acid and caffeine) spiked in the offshore seawater of southwestem Taiwan. Recovery of added compounds by the HTCO method was found to be nearly $100 \%$ for most measurements, with the exception of EDTA where the uncertainty was up to $7 \%$ for a added concentration. The precision is, therefore, believed to be better than $7 \%$ with respect to added compounds in natural seawater (Table 3).

As far as the oxidization efficiency of the persulfate $/ 100^{\circ} \mathrm{C}$ method is concerned, it is dependent on the chloride content of sample, oxidant amount and reaction time. The analytical conditions, which can completely oxidize $\mathrm{KHP}$ in Q- $\mathrm{H}_{2} \mathrm{O}$, did not oxidize KHP efficiently in $\mathrm{NaCl}$ solutions of various chlorinity (Figure 4). Experimental results also showed that increases of oxidant amount and reaction time can greatly enhance the recovery of $\mathrm{KHP}$ in $\mathrm{NaCl}(3.5 \%)$ solutions, thus an operational condition (seawater: $0.5 \mathrm{ml}$; persulfate (10\%): $3 \mathrm{ml}$; reaction time: $13 \mathrm{~min}$.) was set for measuring DOC in natural seawater. However, the optimal condition found from synthetic solutions may not be also optimal for DOC analyses in natural seawater. The data in Table 3 show that the added organic compounds in natural seawater were not totally recovered, indicating the incomplete oxidation of DOC in natural seawater by the persulfate oxidation.

\section{c. Detection limits of methods}

The system blank of the HTCO method was estimated to be $11.69 \mathrm{ngC}$. The detection limit of the instrument ( $35.07 \mathrm{ngC}$ ) is defined as a three-fold intensity of system blank. This signal is equal to that produced from a seawater sample containing $23.38 \mathrm{ngC}$ because the system blank (11.69 $\mathrm{ngC}$ ) is always present and added to any determination. The concentration of detection limit in seawater is therefore equivalent to $29.5 \mu M C$ on the basis of an injection volume of $66 \mu l$ (Table 3 ). This value is relatively smaller than the lowest concentration of DOC found from the deep open ocean (Sugimura and Suzuki, 1988). Obviously, the method is suitable for the measurement of DOC in the ocean. Because the signal of system blank was assumed to be independent of injection volume, 
Table 2. Determination of blank and detection limit for the HTCO and persulfate methods

\begin{tabular}{ccccc}
\hline Method & $\begin{array}{c}\text { System } \\
\text { blank signal } \\
(\mathrm{ngC})\end{array}$ & $\begin{array}{c}\text { System + reagent } \\
\text { (total) } \\
\text { blank signal } \\
(\mathrm{ngC})\end{array}$ & $\begin{array}{c}\text { Detection * limit } \\
\text { of the instrument } \\
(\mathrm{ngC})\end{array}$ & $\begin{array}{c}\text { Detectioi limit \# } \\
\text { in seawater } \\
\mathrm{ngc}(\mu \mathrm{MC})\end{array}$ \\
\hline HTCO & 11.69 & 11.69 & 35.07 & $23.38(29.50)$ \\
Persulfate & $<45.0$ & 450 & 135 & $90.0(15.0)$ \\
\hline
\end{tabular}

* Detection limit of the instrument is defined as three-fold intensity of the system noises.

\# Detection limit in seawater is about one half less than that of the instrument (see explanation in text) and the concentration is calculated on the basis of injection volume, $66 \mu \mathrm{l}$ and $0.5 \mathrm{ml}$, respectively, for the HTCO and persulfate methods.

Table 3. Recovery of added synthetic organics in natural seawater

\begin{tabular}{|c|c|c|c|c|c|}
\hline \multirow{2}{*}{$\begin{array}{l}\text { Organic } \\
\text { compound }\end{array}$} & \multirow{2}{*}{$\begin{array}{c}\text { Added } \\
\mu \mathrm{M}\end{array}$} & \multicolumn{2}{|c|}{ HTCO method } & \multicolumn{2}{|c|}{ Persulfate $/ 100^{\circ} \mathrm{C}$ method } \\
\hline & & $\begin{array}{l}\text { Found } \\
\mu \mathrm{M}\end{array}$ & $\begin{array}{c}\text { Recovery } \\
\%\end{array}$ & $\begin{array}{l}\text { Found } \\
\mu \mathrm{M}\end{array}$ & $\begin{array}{c}\text { Recovery } \\
\%\end{array}$ \\
\hline \multirow{4}{*}{$\begin{array}{l}\text { Potassium } \\
\text { hydrogen } \\
\text { phthalate }\end{array}$} & 100 & 95.8 & 96 & 90 & 90 \\
\hline & 200 & 193 & 96 & 184 & 92 \\
\hline & 300 & 302 & 101 & 264 & 88 \\
\hline & 400 & 396 & 99 & 368 & 92 \\
\hline \multirow[t]{4}{*}{ Oxalic acid } & 100 & 96.3 & 96 & 87 & 87 \\
\hline & 200 & 196 & 98 & 166 & 83 \\
\hline & 300 & 294 & 98 & 267 & 89 \\
\hline & 400 & 400 & 100 & 356 & 89 \\
\hline \multirow[t]{4}{*}{ EDTA } & 100 & 93 & 93 & 90 & 90 \\
\hline & 200 & 188 & 94 & 176 & 88 \\
\hline & 300 & 282 & 94 & 264 & 88 \\
\hline & 400 & 376 & 94 & 360 & 90 \\
\hline \multirow[t]{4}{*}{ Caffeine } & 100 & 101 & 101 & 94 & 94 \\
\hline & 200 & 198 & 99 & 172 & 86 \\
\hline & 300 & 309 & 103 & 243 & 81 \\
\hline & 400 & 416 & 104 & 304 & 76 \\
\hline
\end{tabular}




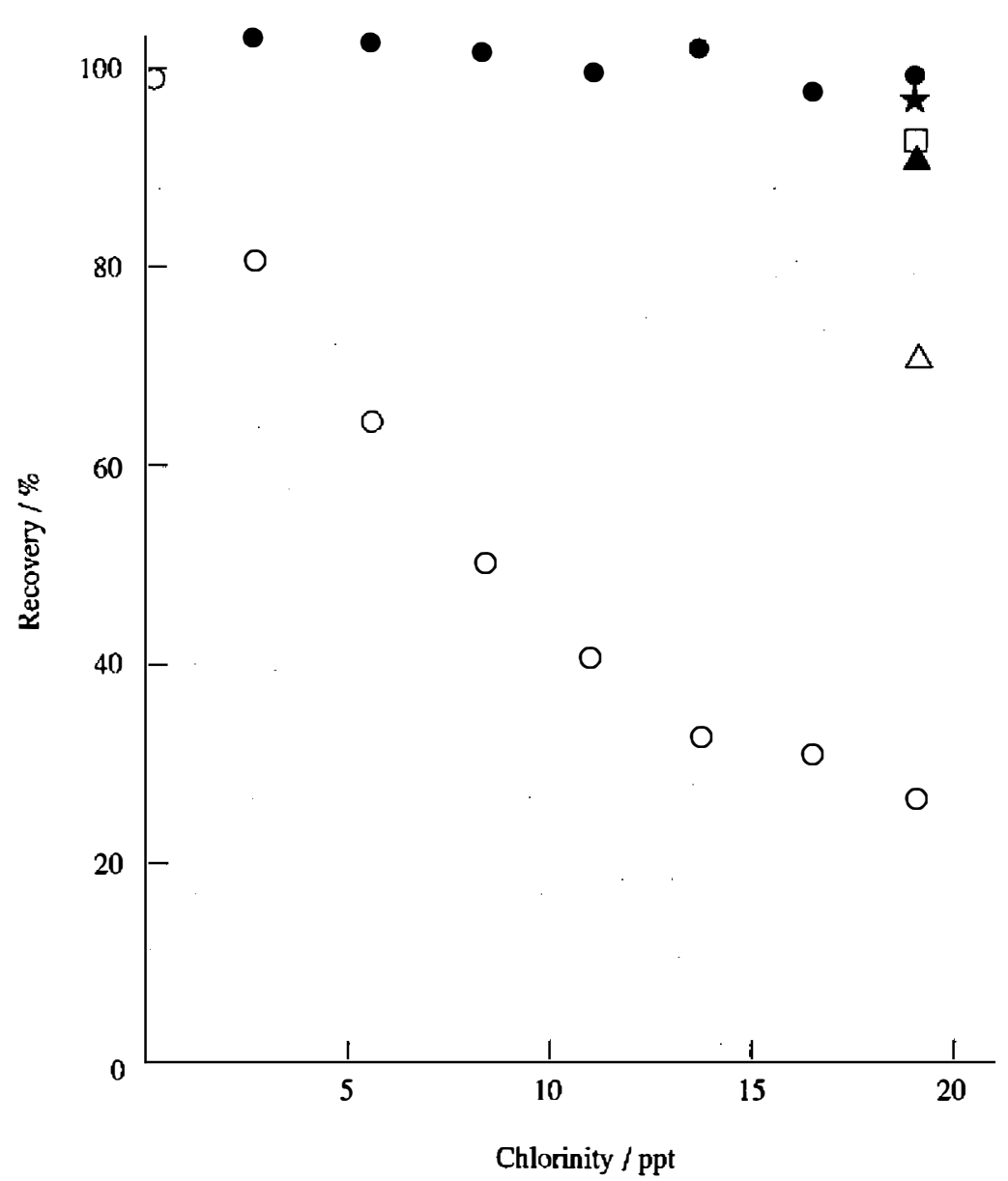

Fig. 4. Effects of chloride content, oxidant volume and reation time on the recovery of $10 \mathrm{ppm} \mathrm{KHP}$ by the persulfate method through the Model 700 of $\mathrm{O}$. I. analyzer: $(O)$ is solutions of various clorinity measured by procedures recommended by the $O$. I. analyzer for non-saline water (sample: $1 \mathrm{ml}$, oxidant: $0.5 \mathrm{ml}$, reaction time: $8 \mathrm{~min}$.), (O) is measured from the modified procedures (sample: $0.5 \mathrm{ml}$, oxidant: $3 \mathrm{ml}$, reaction time: $13 \mathrm{~min}$.), $(\Delta)$ is a solution of $3.5 \%$ $\mathrm{NaCl}$ measured by the conditions of (sample: $0.5 \mathrm{ml}$, oxidant: $0.5 \mathrm{ml}$, reaction time: 10 $\min$.), ( $\square$ ) is measured by the conditions of (sample: $0.5 \mathrm{ml}$, oxidant: $1.5 \mathrm{ml}$, reaction time: $12 \mathrm{~min}$ ), ( $\star$ ) is measured by the conditions of (sample: $0.5 \mathrm{ml}$, oxidant: $1.5 \mathrm{ml}$, reaction time: $13 \mathrm{~min}$.), (A) is measured by the conditions of (sample: $0.5 \mathrm{ml}$, oxidant: $3 \mathrm{ml}$, reaction time: 11 min.).

the increase in injection volume will decrease the concentration of blank in solution, which will result in a decrease of the detection limit. However, this increase of injection volume will shorten the life of catalysts which should be replaced more frequently.

On the other hand, we did not triple the total blank of the persulfate method as the detection limit of the method because the blank was quite high $(0.45 \mu g C)$, the major fraction of which was derived from reagents rather than from system noises. Meanwhile, the total blank was initially recorded in the instrument and signals of standards and 
samples were then automatically offset by this value before they were used for calibration or concentration derivation. Therefore, we still use the triple intensity of system noises as the detection limit of the instrument, although the signal has been blanketed by the reagent blank (personal communication with Dr. S. R. Huang, professor of analytical chemistry, National Sun Yat-sen Univ.). It should be kept in mind, however, the concentration of DOC in seawater, which can be reliably measured, may be greater than the detection limit because the effect of a relatively high reagent blank.

\section{d. Analysis of DOC in seawater}

Sugimura and Suzuki (1988) suggested carrying out the analysis of DOC on board a ship after seawater was sampled and filtered. However, this was difficult to perform on the R/V Ocean Researcher I because of the limitations of ship time and rough shipboard conditions for most seasons of the year while sailing in the surrounding seas of Taiwan. Therefore, the effect of preservation on the DOC concentration should be evaluated prior to the DOC measurement at a land laboratory. For this matter the seawater sample was taken from nearshore southwestem Taiwan, immediately filtered through GF/F filters and acidified with subboiled $\mathrm{HCl}$. The acidified filtrate was equally divided and stored in Pyrex glass bottles at $4^{\circ} \mathrm{C}$ and $-20^{\circ} \mathrm{C}$, respectively. The DOC in the samples of initial and various storage intervals was measured by the HTCO method. Figure 5 shows that the

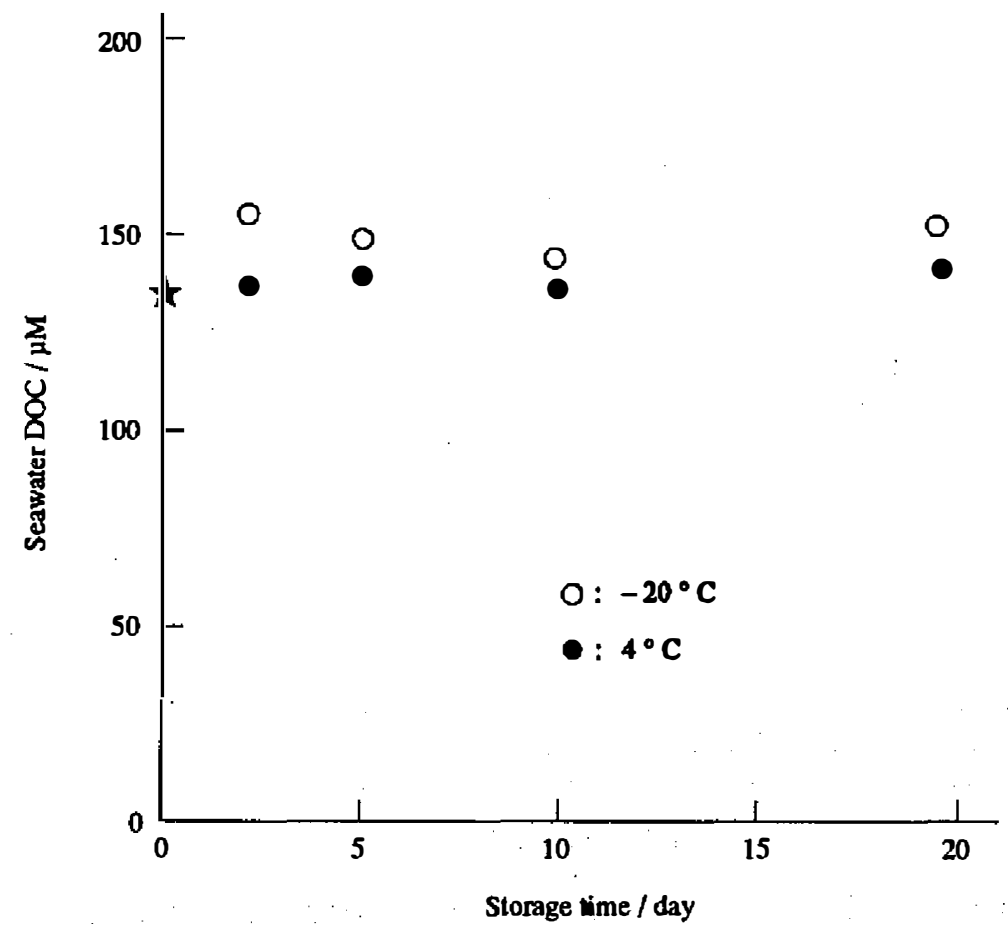

Fig. 5. Effect of sample storing intervals and temperatures $\left(4^{\circ} \mathrm{C}:-20^{\circ} \mathrm{C}: \mathrm{O}\right)$ on the concentration of DOC. 
DOC concentration didn't change while samples were stored at $4^{\circ} \mathrm{C}$ up to 20 days, but the DOC displayed a little increase after storage at $-20^{\circ} \mathrm{C}$. No particular reason can be given for the enhancement of DOC by means of $-20^{\circ} \mathrm{C}$ storage. Nevertheless, the lysis of bacteria and microplankton, which passed through the GF/F filter (nomial pore size: $0.7 \mu \mathrm{m}$ ), was possible. Thus we stored the pretreated samples at $4^{\circ} \mathrm{C}$ until they were analyzed at a land laboratory. The concentrations of DOC in shelf waters off northeastem and southwestem Taiwan (Figure 1) are shown in Table 4 and Figures $6 \& 7$. The concentrations found by the HTCO method are higher than those measured by the persulfate method; the DOC ratio of the persulfate method to the HTCO method ranges from $56 \%$ to $76 \%$ for northeastern shelf water and ranges from $72 \%$ to $95 \%$ for a southwestern water column (st. A). The results imply that the HTCO method provides relatively complete oxidation and yields consistently higher values of DOC over the persulfate method. The concentration of DOC measured by the HTCO method decreases as salinity increases for surface water $(4 \mathrm{~m})$ from st. 2 to st. 11 , indicating a relatively important contribution of DOC from the terrestrial source. The chemical characteristics of terrestrial DOC are somewhat different from those of marine DOC. The former is generally composed of a significant fraction of high molecular-weight geopolymer which is resistant to the persulfate oxidation. As a result, the DOC ratio of persulfate/HTCO oxidations was generally lower for northeastem shelf water than for southwestern shelf water especially for those stations closing to the mainland China and island Taiwan. Although there is no significant difference in the vertical distribution of DOC in northeastem shelf water, it does show a vertical decrease of DOC with depth at station A. A relatively high concentration of DOC in the surface layer may stem from the relatively high biological productivity which results in greater newly formed DOC and gives lower persulfate/HTCO ratios in the surface layer. The sharp decrease of HTCO-DOC below the depth of $100 \mathrm{~m}$ may be due to the microbial degradation of downward fluxed new DOC from surface and be reflected by a relatively high persulfate/HTCO ratio. The relatively lower ratios also appearing in the depth below $500 \mathrm{~m}$ are largely derived from the decrease of persulfate-DOC as a result of cyclings of downward fluxed DOC and sinking particles, as well as from the effect of laterally intruded water masses. Accordingly, DOC may play an important role in carbon biogeochemical cycles in the ocean (Williams and Druffel, 1987; Kumar et al., 1990; Sharp, 1991).

\section{CONCLUSION}

The HTCO method is promising for the analysis of DOC in natural seawater. The method is suitable for shipboard measurement but it also can be carried out in a land laboratory if seawater samples are well preserved. The method measured higher DOC values than did the persulfate method, supporting the previous evidence of incomplete oxidation of DOC by the persulfate method. Both methods, however, provide useful information in the understanding of oceanic DOC biogeochemistry. Preliminary data show 
Table 4. The concentration of DOC in shelf waters off northeastem and southwestern Taiwan

\begin{tabular}{|c|c|c|c|c|c|c|c|c|}
\hline \multirow{2}{*}{\multicolumn{2}{|c|}{ Station }} & \multirow{2}{*}{\multicolumn{2}{|c|}{ Location }} & \multirow{3}{*}{$\begin{array}{c}\text { Temperature } \\
{ }^{\circ} \mathrm{C}\end{array}$} & \multirow{3}{*}{$\begin{array}{c}\text { Salinity } \\
\text { psu }\end{array}$} & \multicolumn{2}{|c|}{ DOC $(\mu \mathrm{M})$} & \multirow{3}{*}{ B/A (\%) } \\
\hline & & & & & & \multirow{2}{*}{$\begin{array}{l}\text { HTCO method } \\
\text { (A) }\end{array}$} & \multirow{2}{*}{$\begin{array}{l}\text { Persulfate method } \\
\text { (B) }\end{array}$} & \\
\hline & - depth & $\mathrm{N}$ & $\mathrm{E}$ & & & & & \\
\hline 1 & $-20 \mathrm{~m}$ & $26^{\circ} 19^{\prime}$ & $120^{\circ} 28^{\prime}$ & 26.08 & 30.81 & 186 & 127 & 68 \\
\hline 2 & $-4 \mathrm{~m}$ & $26^{\circ} 15^{\prime}$ & $120^{\circ} 39^{\prime}$ & 26.22 & 31.63 & 241 & 134 & 56 \\
\hline 3 & $-4 \mathrm{~m}$ & $26^{\circ} 09^{\circ}$ & $120^{\circ} 49^{\prime}$ & 26.23 & 31.93 & 182 & 113 & 62 \\
\hline 4 & $-4 \mathrm{~m}$ & $26^{\circ} 04^{\prime}$ & $121^{\circ} 00^{\prime}$ & 26.40 & 31.71 & 180 & 113 & 63 \\
\hline \multirow[t]{3}{*}{5} & $-4 \mathrm{~m}$ & $25^{\circ} 59^{\prime}$ & $121^{\circ} 09^{\prime}$ & 26.67 & 31.96 & 156 & 114 & 73 \\
\hline & $-20 \mathrm{~m}$ & $25^{\circ} 59^{\prime}$ & $121^{\circ} 09^{\circ}$ & 26.67 & 31.96 & 169 & 118 & 70 \\
\hline & $-75 \mathrm{~m}$ & $25^{\circ} 59^{\prime}$ & $121^{\circ} 09^{\prime}$ & 26.69 & 31.97 & 154 & 107 & 70 \\
\hline 6 & - $4 \mathrm{~m}$ & $25^{\circ} 55^{\prime}$ & $121^{\circ} 18^{\prime}$ & 26.51 & 31.96 & 145 & 104 & 72 \\
\hline 7 & $-4 \mathrm{~m}$ & $25^{\circ} 50^{\prime}$ & $121^{\circ} 29^{\prime}$ & 26.35 & 32.11 & 148 & 112 & 76 \\
\hline 8 & $-4 \mathrm{~m}$ & $25^{\circ} 44^{\prime}$ & $121^{\circ} 40^{\prime}$ & 26.24 & 32.13 & 155 & 114 & 74 \\
\hline 9 & $4 \mathrm{~m}$ & $25^{\circ} 39^{\prime}$ & $121^{\circ} 49^{\prime}$ & 26.00 & 32.18 & 154 & 100 & 65 \\
\hline \multirow{3}{*}{10} & $4 \mathrm{~m}$ & $25^{\circ} 37^{\prime}$ & $121^{\circ} 57^{\prime}$ & 25.18 & 32.28 & 160 & 103 & 64. \\
\hline & - $20 \mathrm{~m}$ & $25^{\circ} 36^{\prime}$ & $121^{\circ} 58^{\prime}$ & 25.19 & 32.27 & 145 & 105 & 72 \\
\hline & $-100 \mathrm{~m}$ & $25^{\circ} 35^{\prime}$ & $121^{\circ} 59^{\prime}$ & 17.38 & 32.63 & 172 & 115 & 67 \\
\hline 11 & $-4 \mathrm{~m}$ & $25^{\circ} 30^{\prime}$ & $122^{\circ} 10^{\prime}$ & - & -1 & 155 & 97 & 63 \\
\hline \multirow{9}{*}{ A } & $-2 \mathrm{~m}$ & $22^{\circ} 20^{\prime}$ & $120^{\circ} 00^{\prime}$ & 29.64 & 32.30 & 182 & 135 & 74 \\
\hline & $-20 \mathrm{~m}$ & $22^{\circ} 20^{\prime}$ & $120^{\circ} 00^{\prime}$ & 29.22 & 32.09 & 156 & 123 & 79 \\
\hline & $-50 \mathrm{~m}$ & $22^{\circ} 20^{\prime}$ & $120^{\circ} 00^{\prime}$ & 28.63 & 32.15 & 161 & 125 & 78 \\
\hline & $-100 m$ & $22^{\circ} 20^{\prime}$ & $120^{\circ} 00^{\prime}$ & 23.28 & $32 \% 6$ & 131 & 124 & 95 \\
\hline & $-200 m$ & $22^{\circ} 20^{\prime}$ & $120^{\circ} 00^{\prime}$ & 16.23 & 32.69 & 131 & 122 & 93 \\
\hline & $-400 m$ & $22^{\circ} 20^{\prime}$ & $120^{\circ} 00^{\prime}$ & 10.37 & 32.53 & 130 & 115 & 88 \\
\hline & $-500 m$ & $22^{\circ} 20^{\prime}$ & $120^{\circ} 00^{\prime}$ & 9.02 & 32.51 & 134 & 101 & 75 \\
\hline & $-600 m$ & $22^{\circ} 20^{\prime}$ & $120^{\circ} 00^{\prime}$ & 7.41 & 32.52 & 121 & 90.7 & 75 \\
\hline & $-830 m$ & $22^{\circ} 20^{\prime}$ & $120^{\circ} 00^{\prime}$ & 6.14 & 32.56 & 128 & 92.3 & 72 \\
\hline
\end{tabular}

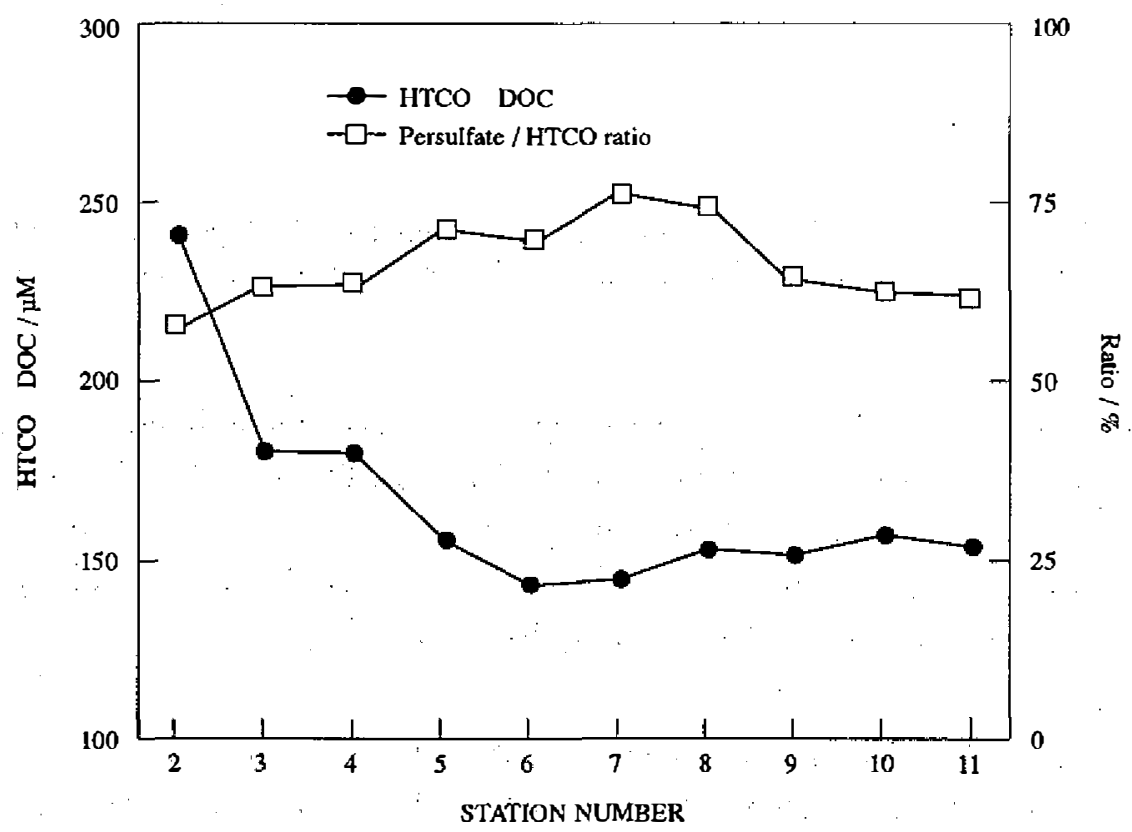

Fig. 6. Distribution of HTCO-DOC (solid circle) and persulfate/HTCO ratio (square) in shelf surface water off northeastern Taiwan. 


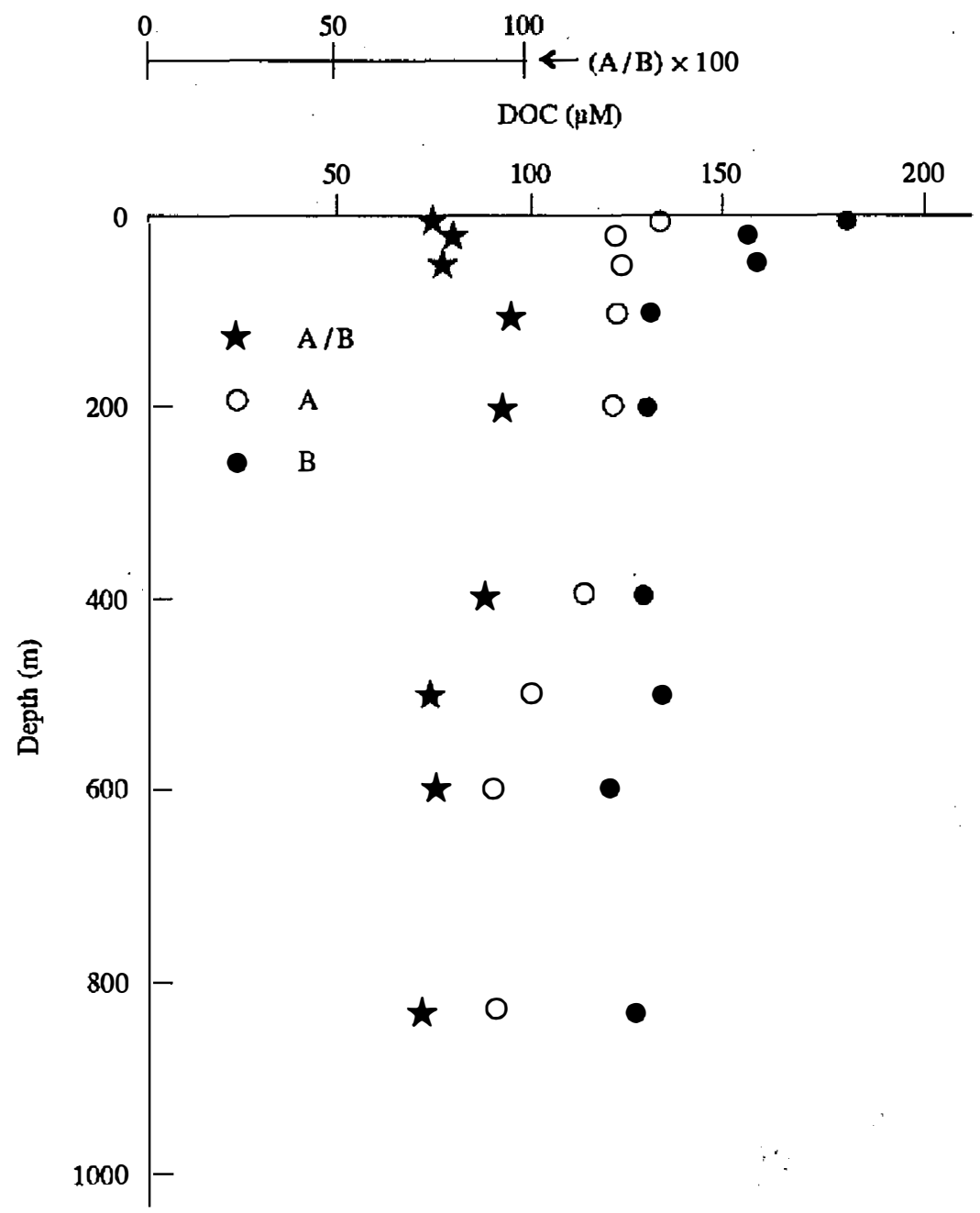

Fig. 7. Vertial profiles of HTCO-DOC (solid circle), persulfate-DOC (open circle) and persulfate/ HTCO ratio (star) in the station $\left(22^{\circ} 20^{\prime} \mathrm{N}, 122^{\circ} 00^{\prime} \mathrm{E}\right)$ off southwestem Taiwan.

that the distribution of DOC was influenced by the terrestrial input, biological productivity and bacterial decomposition. The application of two methods on the detailing study of DOC in the KEEP (Kuroshio Edge Exchange Processes) related areas will be extended from this study. The spatial and temporal distributions of DOC can hopefully provide the signatures of biological productivity resulting from upwelling.

Acknowledgements The authors thank Mr. M. C. Chen for providing data concerning the effect of chloride on oxidation efficiency of DOC by the persulfate method included in his M.S. thesis. We also thank the National Science Council (NSC 80-0209-M110-06), Republic of China for support of this research. The valuable comments suggested by reviewers are greatly appreciated. 


\section{REFERENCES}

Armstrong, F. A. J., P. M. Williams and J. D. H. Strickland, 1966: Photo-oxidation of organic matter by ultra-violet radiation, analytical and other applications. Nature, 211, 481-483.

Bacastow, R. and E. Maier-Reimer, 1991: Dissolved organic carbon in modeling oceanic new production. Glob. Biogeochem. Cycles, 5 (1), 71-85.

Gershey, R. M., M. D. Mackinnon, P. J. le B. Williams and M. Moore, 1979: Comparison of three oxidation methods used for analysis of the dissolved organic carbon in seawater. Mar. Chem., 7, 289-306.

Gordon, D. C. and W. H. Sutcliffe, 1973: A new dry combustion method for the simultaneous determination of total organic carbon and nitrogen in seawater. Mar. Chem., 1, 231-244.

Henneke, E. and G. J. DeLange, 1990: The distribution of DOC and POC in the water column and brines of the Tyro and Bannock basins. Mar. Chem., 31, 113-122.

Kumar, M. D., A. Rajendran, K. Somasundar, B. Haake, A. Jenisch, Z: Shuo, V. Ittekkot and B. N. Desai, 1990: Dynamics of dissolved organic carbon in northwestern Indian Ocean. Mar. Chem., 31, 299-316.

MacKinnon, M. D., 1978: A dry oxidation method for the analysis of the TOC in seawater. Mar. Chem., 7, 17-37.

Menzel, D. D. and R. F. Vaccaro, 1964: The measurement of dissolved organic and particulate carbon in sea water. Limnol. Oceanogr., 9, 134-142.

Romankevich, E. A. and S. V. Ljutsarev, 1990: Dissolved organic carbon in the ocean. Mar. Chem., 30, 161-178.

Sharp, J. H., 1973: Total organic carbon in seawater-Comparison of measurements using persulfate oxidation and high temperature combustion. Mar. Chem., 1, 211-229.

Sharp, J. H., 1991: Review of carbon, nitrogen and phosphorus biogeochemistry. Rev. Geophysics, 648-657.

Sugimura, Y. and Y. Suzuki, 1988: A high-temperature catalytic oxidation method for the determination of non-volatile dissolved organic carbon in seawater by direct injection of a liquid sample. Mar. Chem., 24, 105-13i.

Suzuki, Y., E. Tanoue and H. Ito, 1991: High temperature catalytic oxidation method for dissolved organic carbon determination in seawater-examination and improvement. Deep-sea Res., 1991, in press.

Toggweiler, J. R., 1988: Deep-sea carbon, a burning issue. Nature, 334, 468.

, 1989: Is the downward dissolved organic matter (DOM) flux important in carbon transport? In Productivity of the Ocean; Past and Present, W. H. Berger, V. S. Smetacek and G. Wefer (eds.), John Wiley and Sons, N. Y., 65-83.

, 1990a: Diving into the organic soup. Nature, 345(17), 203-204. . 
1990b: Bombs and ocean carbon cycles. Nature, 347, 122-123.

Williams, P. M. and E. R. M. Druffel, 1987: Radiocarbon in dissolved organic matter in the central North Pacific Ocean. Nature, 330; 246-248. 


\title{
海水中溶解性有機碳之測定：高温催化氧化 法與過硫酸氧化法之比較
}

\author{
洪佳章張偉安 \\ 国立中山大學海洋地質研究所
}

\section{摘 要}

本研究旨在確定高溫催化氧化法之分析條件以測定海水中 溶解性有機碳。此方法乃利用敛/氧化鉊烏催化矵在 $680^{\circ} \mathrm{C}$ 下 分解溶解性有機碳孚二氧化碳, 然後以非散性紅外光譜法测定 二氧化碳之濃度。此方法之海水偵測下限在體積 $66 \mu \mathrm{l}$ 時約孚 $29.5 \mu M C$, 而其不準確度由数種有機物之海水添加試驗碩示約 爲 $7 \%$ 。此方法之偵測下限及精確度將因體積之增加而分別降 低及增加。對於海水中溶解性有機碳之測定, 高温催化氧化法 比過硫酸氧化法快速且可靠, 但分析成本較高。若以高温催化 氧化法於陸上惯验室進行海水分析時, 海水樣本需經現場過滤 , 酸化及儲存於不透光之 $4^{\circ} \mathrm{C}$ 中方能測得可信濃度。高温催化 氧化法測得台灣東北及西南海域海水溶解性有機碳浱度均比利 用過硫酸氧化法測得之灙度高, 碩示過硫酸氧化法無法完全分 解海水中有機碳。高温催化氧化法测得台灣束北海域表水之溶 解性有機碳隨監度之降低而增加, 此表示可能陸源溶解性有機 碳輸入之影響所致。另一方面台灣西南海域之一測站溶解性有 機碳之分佈有隨深度渐減之趋势, 暗示溶解性有機碳分佈與生 物對有機物博换之間的相關性。利用此雨種方法分析台灣束北 海域水圈交换影響下之溶解性有機碳分佈將有助於溶解性有機 碳特性之瞭解。 